\title{
LA SECULARIZACIÓN EN CATALUÑA EN LOS INFORMES EPISCOPALES (1800-1867)
}

\author{
POR \\ Antonio Moliner Prada ${ }^{1}$ \\ Universidad Autónoma de Barcelona
}

\begin{abstract}
RESUMEN
El proceso de secularización en Cataluña entre 1800 y 1867 se refleja en los informes que los obispos de las distintas diócesis envían a Roma. Remarcan el proceso creciente de mundanización y alejamiento de los valores evangélicos en los periodos revolucionarios: aumento de la indiferencia religiosa en las ciudades, corrupción de costumbres por la prensa liberal y circulación de libros impíos y disminución de las prácticas religiosas (cumplimiento dominical, pascual, ayuno y abstinencia). Las nuevas doctrinas, protestantismo y socialismo, derivadas del liberalismo, aparecen como los verdaderos enemigos de la Iglesia.
\end{abstract}

PALABRAS CLAVE: Cataluña; Iglesia católica; siglo XIX; secularización; informes episcopales.

\section{THE SECULARIZATION IN CATALONIA IN THE EPISCOPAL REPORTS (1800-1867)}

\begin{abstract}
The process of secularization in Catalonia between 1800 and 1867 is reflected in the reports that the bishops of the various dioceses sent to Rome. They pointed out the increasing globalization and that the evangelic values were moving away in revolutionary periods, such as the increased of the religious indifference in the cities, the corruption in the liberal press, ungodly books movements and the decrease of religious practices (Sabbath and Easter compliance, fasting and abstinence). Hence, new doctrines derived from liberalism, as the Protestantism and Socialism, appeared as the true enemies of the Church.
\end{abstract}

KEY WORDS: Catalonia; Catholic Church; 19th century; Secularization; Episcopal Reports.

Cómo CITAR ESTE ARTículo / CITATION: Moliner Prada, A. 2018. «La secularización en Cataluña en los informes episcopales (1800-1867)». Hispania Sacra 70, 141: 305-319. https://doi.org/10.3989/hs.2018.023

$\begin{array}{ll}\text { Recibido/Received } & 07-01-2016 \\ \text { Aceptado/Accepted } & 03-02-2016\end{array}$

\section{ESTADO DE LA CUESTIÓN}

El término secularización aparece en la época de la Reforma protestante en el ámbito jurídico. La referencia a la secularisatio se utiliza en las últimas décadas del siglo XVI en los debates entre canonistas franceses, con el significado de tránsito de un religioso regular (fraile) al estado secular. Desde el siglo XVIII la secularización se convierte en una categoría general indisoluble del concepto unitario de tiempo histórico, y en XIX la idea de secularización se expresa con el término "mundanización» (Verweltlichung). ${ }^{2}$

El proceso de secularización entendido como la pérdida de la influencia de la religión y de la Iglesia en la sociedad,

1 antoni.moliner@uab.cat / ORCID iD: http://orcid.org/0000-00025831-4091

2 Lara Martínez 2011: 15-17. como declive de la hegemonía religiosa, fue algo común en la Europa católica del siglo XIX. La tesis de Max Weber considera el avance de la ciencia como uno de los elementos centrales del inicio del "desencantamiento del mundo" (Entzauberung der Welt), la pérdida de la fe del hombre moderno en la búsqueda de explicaciones trascendentes. ${ }^{3}$

Entre las causas que ayudaron al proceso de secularización en Europa en el siglo XIX hay que destacar el crecimiento de las ciudades por el impulso de la Revolución Industrial que desplazó de las zonas rurales a los centros urbanos industriales a las masas obreras incultas y desarraigadas de sus tradiciones. A menudo los cinturones industriales se convirtieron en barrios miserables donde no había parroquias ni pastoral religiosa alguna, y la misma Iglesia no tuvo la

\footnotetext{
3 Monod 2013: 38-54.
} 
sensibilidad adecuada para abordar este problema. En este ambiente, las costumbres y las formas de vida tradicionales cambiaron y condujeron a muchos hombres y mujeres al indiferentismo y al ateísmo. El triunfo del positivismo y del materialismo y la misma libertad de prensa también favoreció la difusión de los principios de incredulidad, y la irreligiosidad contaminó a muchos intelectuales y a la burguesía. En todo caso la Iglesia no adoptó una renovación pastoral capaz de comprender las exigencias de los nuevos tiempos y de crear nuevas instituciones, métodos, y sobre todo mantener un talante de diálogo y comprensión de la nueva realidad. Le faltó sensibilidad y comprensión del nuevo mundo industrial emergente. ${ }^{4}$

En el debate en torno al hecho religioso en la modernidad es conveniente utilizar el concepto de «secularización conflictiva» propuesto por Julio de la Cueva, por que el papel de la religión en la esfera pública no puede entenderse sin el conflicto en el plano político y cultural. ${ }^{5}$ Más aún en el caso de España, país de tradición católica, donde al no producirse una secularización interna de la propia religión ha provocado de este modo que el proceso secularizador se haya llevado a cabo contra la religión y la Iglesia. ${ }^{6}$

La crisis del Antiguo Régimen y la emergencia del régimen liberal provocó en la Iglesia una crisis, al perder su poder económico con las desamortizaciones y disminuir el control que ejercía sobre la sociedad. El Estado liberal fue ganando espacios para consolidar su proyecto político en el cual la Iglesia quedaba bajo su tutela. La respuesta de la Iglesia fue contundente, una oposición absoluta y total a tales cambios. La confrontación llevó a los liberales a argumentar que la Iglesia impedía el progreso, mantenía a la población en el obscurantismo, vivía en la ociosidad (principalmente el clero regular) y era necesario replantear su papel y buscar una nueva organización eclesial que diera al clero parroquial un papel central. La Iglesia vio en la Revolución liberal, en la línea del pensamiento reaccionario, el fruto de una conspiración diabólica que se había iniciado con la Reforma protestante, continuada con la masonería y después con el socialismo, anarquismo y otras corrientes del mundo moderno. ${ }^{7}$ Esta visión esquemática, con diversos matices, la encontramos presente en la mayoría del episcopado y entre el clero.

La vivencia de la religión cambió de algún modo en medio de la crisis del Antiguo Régimen y el advenimiento de la sociedad liberal. Aunque la religión continuó siendo un instrumento importante de cohesión de la sociedad al que el liberalismo de orden nunca renunció, los nuevos valores introducidos a través de la cultura liberal, democrática y republicana y las transformaciones económicas y sociales modificaron paulatinamente el comportamiento religioso de los católicos. El conflicto se desarrolló cuando el Estado liberal intentó imponerse en las esferas que controlaba y monopolizaba tradicionalmente la Iglesia. La laicización de la política constituyó una auténtica revolución y la secularización supuso el fin del monopolio religioso, espiritual, ético y cultural de la Iglesia.

La Revolución liberal en España encontró un clero y episcopado poco preparado y en su mayoría hostil a los

\footnotetext{
4 Laboa 1994: 35-36.

5 De la Cueva Merino 2015: 365-395.

6 Pérez-Agote Poveda 2007: 65-82.

Figuerola, Martí y Raguer 2005: 127-128.
}

cambios. Y cuando finalizó la contienda carlista de 18331839 tuvo que aceptar la nueva situación por necesidad de supervivencia más que por convicción. Faltó un liberalismo católico abierto y en cambio dominó la línea más conservadora e integrista en la Iglesia.

Disponemos de diversos estudios importantes para conocer la evolución de la institución eclesiástica en Cataluña de finales del siglo XVIII y en el siglo XIX. Entre estos destacan el de Joaquim M. Puigvert sobre el mundo parroquial, los orígenes sociales y geográficos de los párrocos, niveles de vida, formación cultural y su papel de intermediarios culturales; el de Gaspar Feliu sobre las actitudes del clero barcelonés durante el Trienio Liberal; los de Joan Bada y Casimir Martí para la diócesis de Barcelona, en dos momentos clave, el primer tercio del siglo XIX y durante el gobierno del obispo Josep Costa i Borràs, en los años cincuenta; y los relativos a la Iglesia leridana en el siglo XIX, de Antoni Sánchez Carcelén sobre el reinado de Fernando VII, de Josep M. a Pons i Altet sobre el obispo Marià Puigllat i Amigo (1862-1870), y de Ferran Closas Salinas sobre el obispo Pedro Cirilo Úriz Labayru (1850-1861). ${ }^{8}$

En cuanto a las corrientes de pensamiento dentro de la Iglesia cabe destacar los trabajos de Ramon Corts i Blay sobre el arzobispo de Palmira Fèlix Amat, al que considera como preilustrado, colaborador con el gobierno de José I, cercano al pensamiento jansenista, aunque no asimiló sus contenidos, y no dio soporte al liberalismo de las Cortes del Trienio liberal sino a su política religiosa, que en muchos aspectos se parecía al reformismo que él mismo propugnaba9; el de Julián Barrio Barrio sobre la figura del obispo de Astorga Fèlix Torres Amat ${ }^{10}$; el de Josep M. Fradera sobre la figura del clérigo e insigne filósofo Jaume Balmes que ayudó a adaptar a la Iglesia a la nueva sociedad industrial y a la corriente liberal frente al carlismo ${ }^{11}$; los de Jordi Figuerola sobre el obispo Strauch, asesinado durante el Trienio, y sobre el obispo Morgades, reorganizador de la Iglesia catalana al final del siglo $\mathrm{XIX}^{12}$; los estudios de Joan Bonet i Baltá i Casimir Martí y Antonio Moliner Prada sobre la corriente integrista ${ }^{13}$; el de Carmen Ibáñez Gisbert sobre el pontificado de Benito Vilamitjana i Vila en la diócesis de Tortosa en la coyuntura del Sexenio democrático ${ }^{14}$ y los de Lluís Ferran Toledano y Jordi Canal sobre el carlismo y la Iglesia en la tercera guerra carlista. ${ }^{15}$

No disponemos de estudios concretos sobre la práctica religiosa o el peso del catolicismo en la sociedad industrial y urbana de Cataluña; tampoco sobre las funciones sociales precisas que tenía antes y después de la ruptura que significó la Revolución liberal. ${ }^{16}$ Un trabajo pionero es el de Jordi Figuerola («Movimiento religioso, agitación social y movilización política»), en el que pone de relieve la importancia que tuvo Jaume Balmes en la apertura de nuevos caminos frente a la opinión de la mayoría de eclesiásticos

8 Puigvert 2000; Feliu 1972; Bada 1986; Martí 1984; Sánchez Carcelén 2012; Pons i Altet 2005: 225-238; y Closas Salinas 2003.

9 Corts i Blay 1992.

10 Barrio Barrio 1976.

11 Fradera 1996.

12 Figuerola 1988; ibídem 1994a.

13 Bonet i Balta y Martí 1990; Moliner Prada 2000.

14 Ibáñez Gisbert 1991.

15 Toledano González 2001; ibídem 2002; ibídem 2004; Canal 1998.

16 Fradera 2002: 106. 
que pensaban que la Revolución liberal pretendía abatir el razonamiento, destruir el mundo y arrasar el poder de la Iglesia sobre la sociedad cristiana. ${ }^{17}$

No es suficiente conocer la evolución de las estructuras eclesiásticas y de los obispos y de su mayor o menor adaptación a los cambios del siglo XIX. Hay que comprender lo que ocurrió dentro del catolicismo en una época de cambio social y de crisis de valores. En este sentido la visión del episcopado sobre el proceso de secularización de la sociedad es un referente importante, junto a otras fuentes literarias y periodísticas o de algún eclesiástico como Balmes que matizan esta opinión. Cataluña, como el resto de España, fue escenario de dos evoluciones simultáneas, probablemente interrelacionadas. Por un lado las manifestaciones nítidas de anticlericalismo y de anticatolicismo puestas de manifiesto en 1823, 1835, 18541856 y $1868-1873$, y por otro los progresos de secularización de la sociedad, el alejamiento más o menos explícito de determinados grupos de la población de las filas y tutela del catolicismo. Este alejamiento o pérdida de intensidad en la religiosidad, que se puede observar a través del grado de cumplimiento pascual entre los católicos, también se debería contrastar de manera adecuada con los esfuerzos de recristianización y de transformación de la práctica religiosa que se produjeron al mismo tiempo.

Cataluña ofrece a lo largo del siglo XIX un escenario novedoso en cuanto a la exportación de nuevas formas de organización y propaganda religiosa, de múltiples congregaciones, de una gran actividad editorial católica, de nuevas formas de piedad para hacer frente a los retos de la nueva sociedad. Se convirtió en las décadas centrales del siglo en el laboratorio por excelencia de las nuevas modalidades de propaganda y de organización católicas a escala nacional y fue el seminario experimental para toda España. ${ }^{18}$ De modo que la renovación institucional y cultural del catolicismo catalán es compatible y a su vez respuesta a la secularización en ciernes. Son, como señala J. M. Fradera, dos caras de la misma moneda de una sociedad sometida a presiones intensas derivadas del proceso de industrialización y de urbanización. ${ }^{19}$

\section{LA IGLESIA FRENTE A LA REVOLUCIÓN LIBERAL}

La Guerra de la Independencia, o Guerra del Francés en la denominación catalana (1808-1814) ${ }^{20}$, perjudicó de alguna manera a la Iglesia, los ejércitos se apoderaron de los diezmos y de los bienes eclesiásticos, los monasterios fueron convertidos en establos o depósitos de municiones y muchos acabaron en estado ruinoso. La Iglesia experimentó también una disminución de sus efectivos, principalmente del clero regular. ${ }^{21}$ La vivencia religiosa era muy distinta según los territorios, ocupados o no por los ejércitos

17 Figuerola 1994b: 48 y 49.

18 Fradera 1992: 245.

19 Fradera 2002: 118.

20 El Bicentenario ha aportado una serie de estudios sobre la Iglesia y otras cuestiones generales de gran interés. Entre ellos destacan: Barbastro Gil 2013; La Parra 2015: 855-867; Sánchez Carcelén 2010: 119-140; Sauch Cruz 2011; Arnabat Mata 2013; Fontana 2008; Ramisa Verdaguer 2008; Moliner Prada 2007.

21 Callahan 1989: 106. napoleónicos. Raymundo Ferrer, del Oratorio de San Felipe Neri, señala en el caso de Barcelona, ocupada desde febrero de 1808 hasta mayo de 1814, la participación masiva de los católicos en las prácticas religiosas, tan solo varió el boato en la celebración de la Semana Santa y procesiones del Corpus. Refiriéndose a la fiesta de Santa Eulalia, patrona de la ciudad, anota en su dietario el 13 febrero 1809 los actos piadosos celebrados en la iglesia catedral: de 11 a 12 de la mañana lectura de un punto de meditación, después la misa, lectura y al final canto de los gozos por parte de los monaguillos acompañados del órgano. Y concluye: «iQué sencillez! Pero iqué devoción! iQué ternura se nota en los devotos concurrentes!». ${ }^{22}$ Otras prácticas piadosas en las iglesias de Barcelona son las cuarenta horas eucarísticas, el octavario al Santísimo Sacramento, el novenario a las almas del purgatorio, la comunión general, la oración mental, el catecismo y plática moral, el rosario, los sermones cuaresmales y los ejercicios espirituales.

La Iglesia y la religión fueron instrumentos de socialización para explicar el conflicto bélico entre el pueblo, sobre todo en el mundo rural, que vio la ocupación como una clara agresión contra la propia identidad individual y comunitaria. ${ }^{23}$ Las partidas de Cruzada, a cuyo frente se pusieron numerosos frailes y clérigos, demuestra la importancia movilizadora de la religión en esta guerra calificada de "santa», contra el maligno Napoleón, heredero y difusor de las ideas revolucionarias francesas. ${ }^{24}$ Las fiestas patrióticas para celebrar las victorias y honrar a los héroes muertos en los combates o a los represaliados, fueron constantes. Los catecismos políticos, los discursos de los clérigos y los sermones adquirieron de este modo un valor especial para exaltar la resistencia patriótica y justificar la violencia. En los sermones se apela al providencialismo, a los Macabeos como ejemplo para morir en defensa de la patria, de la religión y del rey, y a las nefastas consecuencias que tendría la victoria de Napoleón en España. ${ }^{25}$

Ciertamente las formas tradicionales de las prácticas religiosas se debilitaron durante la contienda por los desplazamientos de la población y la desaparición de los controles civiles y eclesiásticos tradicionales existentes. Los obispos de las diócesis catalanas abandonaron sus diócesis, excepto los de Vic y Girona, y se refugiaron en Mallorca, y los párrocos dedicaron gran parte de su tiempo para poder sobrevivir en circunstancias difíciles. Acabadas las hostilidades, los obispos estaban convencidos de que el debilitamiento de la vigilancia de los eclesiásticos ocasionada por la guerra había conducido a una inmoralidad general (separaciones matrimoniales, inobservancia de las fiestas eclesiásticas, la costumbre de las palabras obscenas, injurias a los ministros de la religión, irreverencias en los templos, etc.). Los eclesiásticos vieron en Fernando VII al ángel vengador que purificaría a la nación de su corrupción y permitiría a la Iglesia proseguir con su revolución espiritual, en consonancia con el espíritu de la Restauración europea simbolizado por la

22 Ferrer 2010: vol. III, 74.

${ }^{23}$ Un balance historiográfico en Andrés-Gallego 2009: 749-781. Sobre la guerra religiosa remito a los estudios de Revuelta González 2009: XXX; Cuenca Toribio 2009: 48-68; y Barnosell Jordá 2010.

24 Pascual 2000; Martínez Ruiz y Gil 2010: 151-220; Moliner Prada 2005: 277-304.

25 Barrio Gozalo 2012: 9-42; Martínez Ruiz y Gil 2010: 234-236. 
Santa Alianza. ${ }^{26}$ Ronald Fraser señala que tras la contienda se incrementaron en Cataluña las proposiciones denunciadas al tribunal de la Inquisición, por el conflicto social vivido bajo la lucha antinapoleónica y el deseo de venganza por parte de los acomodados y del clero ultra. ${ }^{27}$

En cuanto a la práctica del divorcio, amancebamientos o concubinatos en esta época, Marie Costa deduce que al no aplicarse la ley del divorcio estipulado en el Código Civil napoleónico, el papel del Tribunal Eclesiástico y del vicario general de Barcelona fue muy limitado entre 1808 y 1814. La falta de control de las autoridades propició durante este período la práctica ilegal, que se regularizó después. Si bien la mayoría de las demandas se realizaron entre 1775 y 1808 a instancias de las mujeres, a partir de 1814 se incrementaron las masculinas. Los motivos expuestos por los maridos para divorciarse de sus mujeres eran la excesiva libertad, el adulterio y la complicidad de las autoridades francesas. Se nota una cierta fragilidad en los matrimonios, que se acentuó aún más durante el Trienio liberal, periodo en el que aparecen más pleitos de divorcio formal y sentencias relativas a la separación de los consortes. ${ }^{28}$

La Iglesia española que había sufrido una honda transformación en el primer experimento liberal gaditano, se vio sometida a un retroceso, igual que en el campo político, tras el golpe de Estado de Fernando VII en 1814. Casi el 50 $\%$ de los obispos españoles en 1820 habían sido designados por el monarca durante el sexenio absolutista, imponiendo así una línea de continuidad con el Antiguo Régimen al elegir para las sedes vacantes a aquellos eclesiásticos que se habían manifestado abiertamente hostiles a las ideas liberales y a las reformas de las Cortes.

La Iglesia vivió un enfrentamiento continuo con los gobiernos del Trienio liberal, el primero estalló cuando exigió a los obispos fidelidad y aceptación del texto constitucional. Las tensiones se incrementaron con el proyecto de las Cortes presentado por el clérigo liberal alicantino Antonio Bernabéu de remoción de personas eclesiásticas no acordes con el sistema constitucional y cuando el gobierno prohibió la concesión de órdenes mayores mientras no se resolviera el problema económico. Los obispos electos designados en las diócesis vacantes por el gobierno, miembros de los distintos capítulos catedralicios, nunca fueron aceptados por el nuncio y por Roma, solo tres de un total de catorce candidatos episcopales fueron preconizados en consistorio.

La experiencia del Trienio liberal fue traumática para gran parte del episcopado. La cuestión de la secularización de los religiosos que pasaban a manos de los obispos de sus diócesis creó mucha oposición entre los prelados. ${ }^{29}$ Tras la supresión de los jesuitas (15 agosto 1820), las Cortes aprobaron el decreto de disolución y reforma de las órdenes religiosas (25 octubre 1820), y la aplicación de sus bienes al pago de la deuda pública. Ello provocó una desbandada de los religiosos de sus conventos, más de ocho mil de los treinta y tres mil que había en España. El drama de los secularizados, el fracaso de la dotación del clero y la decadencia de la vida conventual muestran un

\footnotetext{
26 Callahan 1989: 104.

27 Fraser 2006: 535.

28 Costa 2011: 263-273.

29 Rodríguez López-Brea 2002: 330-335.
}

panorama complejo de la Iglesia española. ${ }^{30}$ La mayor parte del clero y algunos obispos, reacios al liberalismo, apoyaron desde el principio el movimiento realista. El enfrentamiento entre clero y liberalismo llegó a ser violento en 1823, especialmente en Cataluña. ${ }^{31}$

Los obispos se obsesionaron con la Inquisición, que fue restaurada en julio de 1814 para defender la ortodoxia doctrinal y luchar contra la propagación de los libros prohibidos, y en 1824 se crearon las Juntas de fe diocesanas con el mismo objetivo. ${ }^{32}$ El Consejo Real ordenó en 1829 de nuevo castigar todo tipo de delitos: escándalos, separaciones matrimoniales, vida licenciosa de los cónyuges, amancebamientos, inobservancia de las fiestas eclesiásticas, blasfemias e injurias a los ministros de la religión y las irreverencias en los templos. La Iglesia española se limitó a acentuar su condición de víctima de la revolución, sobre todo en el campo material y humano, y a lamentarse de la corrupción general de costumbres y de la propaganda de escritos perniciosos. ${ }^{33} \mathrm{El}$ mismo nuncio Tiberi en sus despachos se refiere al excesivo celo del episcopado español en la prohibición de publicaciones muchas veces poco sospechosas de atentar contra la religión. ${ }^{34}$

En medio de la guerra civil carlista (1833-1840) se desarrolló un proceso de anticlericalismo violento, la matanza de frailes en 1834 y 1835, que precipitó el programa liberal de la desamortización y exclaustración. ${ }^{35}$ Correspondió a Mendizábal la supresión de los monasterios de frailes (1835) y la venta pública de sus bienes (1836). La política eclesiástica de los gobiernos posteriores se dirigió a castigar a los clérigos que se opusieran al régimen y a crear una organización de la Iglesia subordinada al Estado. Durante la regencia de Espartero (1840-1843) prosiguió la desamortización del clero secular y se planteó una reorganización de las parroquias y de las diócesis.

La Iglesia perdió terreno de forma ostensible en las ciudades. Balmes, observador perspicaz de la realidad de Barcelona, se lamentaba de la desaparición de una idealizada España católica donde la religión y la piedad inundaban las calles y los paseos del reino en provecho de una sociedad ocupada de los adelantos fabriles, mercados, lujo y placeres, de su delirio político y de su refinado egoísmo. ${ }^{36}$

Moderados y progresistas no dudaban de la importancia de la religión para justificar el orden social y procuraron encontrar para la Iglesia una función razonable. La cuestión que les separaba era el tipo de Iglesia y de religión que debía tener el país. Los progresistas nunca pusieron en duda la hegemonía espiritual de la Iglesia, aunque atacaban sus riquezas y grandeza. Los moderados, que gobernaron entre 1844 y 1854 , pensaban que la Iglesia tenía una función indispensable para el mantenimiento del orden público y para ello el clero era muy útil al predicar la obediencia a las leyes y la resignación. La Iglesia se recuperó en esa década y la reconciliación llegó con el Concordato de $1851 .^{37}$

\footnotetext{
30 Teruel 1996.

31 La Parra 1998: 45-46; Alonso 2014: 96-99.

32 La Parra y Casado 2013.

33 Revuelta 1979: 67-68.

34 Cárcel Ortí 1976.

35 Moliner Prada 1997: 497-541; ibídem 1998: 69-125.

36 Callahan 1989: 181.

37 Shubert 1991: 215.
} 
La Revolución liberal hizo mella en el clero antiguo y provocó la reflexión entre los católicos más conscientes sobre las actitudes que la Iglesia debía de adoptar ante la nueva situación política y social. Unos soñaban con una restauración completa de la Iglesia como en 1814 o 1823; otros pensaban que la revolución era irreversible y buscaron nuevas soluciones para afrontar las relaciones de Iglesia y Estado y nuevos instrumentos para la acción pastoral. Los primeros optaron por los lamentos y ante los pronósticos catastrofistas de futuro defendieron ante todo la honra y la gloria del clero español, como el periódico La Voz de la Religión, el obispo Josep Caixal i Estradé y los frailes Atilano Melguizo y José de Areso. ${ }^{38}$ Los segundos, en cambio, se imaginaron un futuro mejor que había que conseguir, más allá de las lamentaciones, entre ellos Joaquim Roca y Cornet, colaborador en la revista La Religión, Jaume Balmes director de El pensamiento de la Nación y el periodista mallorquín José María Quadrado autor del artículo «El clero nuevo» (1843) publicado en El Católico (1843).

Ante los desafíos de la Iglesia Quadrado propone tres objetivos: el nuevo clero debe basar su influjo en la perfección moral y en los servicios al prójimo; debe ser independiente del poder temporal; debe conocer mejor las necesidades del mundo para comunicar el evangelio y debe tener una mejor formación teológica. A Balmes le preocupa sobre todo la vida de los párrocos, la confrontación del sacerdote con la incredulidad, por lo que debe cambiar el lenguaje para que sea comprensible por los hombres, su formación intelectual y la función de las órdenes religiosas en un mundo que ha cambiado. Ambos apuestan por un clero virtuoso, activo y útil, independiente y servidor del pueblo, ilustrado, tolerante y abierto a la cultura y a las novedades del siglo. ${ }^{39}$ Ciertamente Balmes estaba convencido de que el catolicismo podía encontrar mayor espacio para su desarrollo bajo el régimen político liberal que en los gobiernos absolutistas. ${ }^{40}$

La pérdida de influencia de la Iglesia a lo largo del siglo XIX se debió también a que la formación de los seminaristas y futuros sacerdotes tenía un carácter cerrado y aislado frente a la cultura y mentalidad secular. La misma separación física de los seminarios del mundo que los rodeaba acentuó el aislamiento intelectual del clero. ${ }^{41} \mathrm{~A}$ principios del siglo el clero español se caracterizaba por tener graves deficiencias intelectuales y en su conjunto carecía de inquietudes reformistas. La preparación académica y moral adolecía de falta de actualización y modernidad y las ideas ilustradas tenían escaso calado en la mayoría de clérigos. ${ }^{42} \mathrm{Si}$ bien la reforma de la educación del clero de 1852 incorporó las ciencias al programa de estudios, impartido en latín y estrechamente centrado en lo eclesiástico, proporcionó a su vez una educación similar a los seminaristas introduciendo la llamada "carrera breve» para preparar tantos sacerdotes como fuera posible a corto plazo. Dicho plan de estudios contemplaba tan solo tres años de latín, uno de filosofía y dos de teología, promocionando a clérigos poco formados que estaban condenados a las parroquias rurales sin esperanza de mejora. ${ }^{43}$

\footnotetext{
38 Revuelta González 2005: 84.

39 Ibídem: 85-90.

40 Fradera 1996: 346

41 Vázquez Vilanova 2002: 227-242.

42 Barbastro 1987: 3-5.

43 Callahan 1989: 214.
}

Enric Subirà, que ha estudiado el Seminario de Barcelona, afirma que la visión que se le daba al seminarista del mundo era muy negativa, separado de él, con una formación de teología dogmática y moral, más que una teología positiva. Se le preparaba exclusivamente para las exigencias de su ministerio sin una formación científica y profana. Los reglamentos imponían una disciplina severa, que dejaba poca libertad de iniciativa y les daba en cambio una seguridad, su cumplimiento por la obediencia ciega y poco diálogo con los sacerdotes del exterior. La visión negativa de la sociedad como falta de moral y los mismos contenidos de los estudios son -entre otros aspectos - los que creaban un modelo de sacerdote que podía llevarlo al clericalismo. ${ }^{44}$

La espiritualidad de los seminaristas se fundamenta en la obligatoriedad de la asistencia a la misa diaria, la oración mental, la recepción de la comunión que se introduce paulatinamente, a mitad del siglo XIX los domingos y días festivos y un día al mes comunión general. A partir de 1858 se incorpora el cargo de "padre espiritual» confiado a los jesuitas que llevó consigo la realización de los ejercicios anuales de San Ignacio, junto a otras prácticas de piedad un día de retiro mensual, frecuencia de los sacramentos, rosario, lectura espiritual, meditación y examen de conciencia. También los seminaristas participan en la liturgia de las horas, después de la misa matutina rezan Prima y Tercia, al mediodía Sexta y Nona y por la tarde Vísperas y Completas. Las devociones a la Virgen, patronos de la Iglesia, San José, el Apostolado de la Oración y devoción al Sagrado Corazón fueron comunes en los seminarios del siglo XIX. ${ }^{45}$

En cuanto a la formación teológica de los obispos hasta mediados del siglo en líneas generales es pobre. Un primer grupo se manifestó hostil a las nuevas ideas y no pocos simpatizaron con el carlismo, como Joaquín Abarca, obispo de León, y Félix Herrero Valverde de Orihuela. Algunos fueron más abiertos como Judas José Romeo y liberales como Pedro González Vallejo, Félix Torres Amat y A. Posada Rubín de Celis, éste incluso masón.

A partir del Concordato de 1851 la figura de Antonio María Claret fue decisiva en los nombramientos de obispos, todos ellos adheridos al papa Pío IX y al régimen monárquico-liberal, o al menos no eran hostiles a él. Aunque unos pocos habían apoyado al realismo, como Fray Cirilo de Alameda nombrado arzobispo de Toledo en 1857, y el carlista Josep Caixal i Estradé que llegó a ser capellán del ejército carlista en $1873 .{ }^{46}$

La labor pastoral de los prelados fue en este periodo más cuidada en relación a los seminarios, misiones populares, fundaciones y devociones. En sus pastorales y en los informes los obispos se preocupan un poco más de cuestiones de piedad, enseñanza catequética, orientaciones cuaresmales, devociones a la Virgen, San José o al Sagrado Corazón. Aunque los temas preponderantes son las relaciones Iglesia-Estado y los Ilamados males del siglo: liberalismo, propaganda protestante, socialismo, costumbres públicas y privadas, familia, etc.

Los cultos populares en este periodo son por lo general barrocos, poco litúrgicos: romerías, peregrinaciones, procesiones, rezos, novenas, los gozos cantados, etc. Los

\footnotetext{
44 Subirá i Blasi 1993: 195-197.

45 Ibídem:183-187.

46 Revuelta González 1989: XXXV, 201.
} 
devocionarios más difundidos son los de padre Antonio María Claret, El camino recto y seguro para llegar al cielo, (1a edición en catalán en 1843 y en castellano en 1846) y el del jesuita José Mach Ancora de salvación (1a edición de 1854). ${ }^{47}$ Probablemente el libro de Claret fue el best-seller de todos los libros publicados en la España moderna, pues al comenzar el siglo XX se habían vendido varios millones de ejemplares. En total se hicieron 185 ediciones de la obra en castellano y 45 en catalán. La creación de la Librería Religiosa de Barcelona en 1848 por el obispo Josep Caixal i Estradé, con la colaboración del padre Antonio María Claret, contribuyó a la expansión de las publicaciones de contenido religioso y a la renovación de la piedad popular en toda España. La primera obra editada fue el Catecismo explicado por A. M. Claret (1848), obra que reúne las dos características fundamentales de la "Librería Religiosa», la apologética y la piedad. ${ }^{48}$ Claret abandonó la costumbre tradicional de organizar el texto en torno a los Diez Mandamientos, para hacerlo girar en torno a las cuestiones de fe, esperanza, caridad y buenas obras. ${ }^{49}$ Otro catecismo muy difundido fue el del obispo Josep Costa i Borràs, bilingüe catalán-castellano (1864), que tuvo muchas reediciones. En cuanto a los libros apologéticos se publicaron en castellano las obras francesas de aquel momento y algunas originales como la de Eduardo María Vilarrassa, La independencia y el triunfo del Pontificado (1860).

Y como el ambiente religioso en todo el país era desolador, como constató el padre Claret en sus misiones populares por toda Cataluña y España, multiplicó los escritos cortos y de fácil lectura, para que ilustraran al pueblo sencillo y lo ayudaran a vivir más cristianamente. Los Opúsculos en su mayoría publicados por este autor, contienen de 15 a 40 páginas y costaban entre 15 y 30 reales el centenar, dirigidos a los jóvenes, religiosas, doncellas, padres de familia, viudas, niños, sacerdotes, etc.Junto a ellos hay que señalar las hojas volantes, de pliego, medio pliego, cuartilla y octavilla. Su precio oscila entre 64 reales la resma (unos 500) las hojas de pliego y 1.000 de medio pliego, etc. En ellas se recoge las devociones más tradicionales, a Cristo crucificado, a María Santísima, a San Miguel, al Ángel de la guarda, a las almas del Purgatorio, que conformaban las novenas, trisagios y llenaban los devocionarios de aquella época. La mayoría de estas hojas tienen un carácter devocional, escritas en verso y con cánticos populares. Hojas que se recitaban en las iglesias, en las familias y en las escuelas y que han conformado las devociones populares de los españoles también durante la primera mitad del siglo XX. ${ }^{50}$ Antonio María Claret Claret es prototipo de sacerdote virtuoso, preocupado por difundir la palabra de Dios por todo los medios posibles, moralista paternal y rígido al mismo tiempo, su persona suscitó apoyos fervientes y detractores. ${ }^{51}$

El obispo Josep Caixal i Estradé, que tenía una formación más sólida e intelectual, se cuidó de publicar en la Librería Religiosa ediciones clásicas, como Las confesiones de San

47 Ibídem: XXXV, 161-163.

48 Borràs i Feliu 2006: 38.

49 Callahan 1989: 233.

50 Borràs i Feliu 2006: 39; Callahan 1989: 230-231.

51 El padre Antonio María Claret fundó en 1849 en Vic la congregación de los Misioneros Hijos del Corazón de María y en 1855 en Cuba las Religiosas de la Congregación de María Inmaculada.
Agustín y de autores del siglo de oro (Santa Teresa de Jesús, Alfonso Rodríguez, Luis de Granada, etc.) junto a las grandes obras de espiritualidad de siempre (Kempis, San Francisco de Sales, Croiset, y otros). Como se puede ver, constituyó una gran empresa editorial. Desde su fundación en 1848 hasta 1866 publicó 2.811.100 tomos de varios tamaños, 2.509.500 opúsculos y 4.249 .200 carteles de catecismo y hojas volantes (un total de 9.569 .800 impresos en 18 años, más de medio millón por año). ${ }^{52}$

El crecimiento de las órdenes religiosas en Cataluña a lo largo del siglo XIX fue espectacular, sobre todo a partir de 1848 y del Concordato de 1851, el periodo álgido se sitúa entre 1874 y 1887, con el objeto de mantener la presencia católica desde instancias civiles, no de poder institucional y político como en el Antiguo Régimen. Diversas instituciones civiles encargaron a comunidades, principalmente de monjas, atender sus hospitales o escuelas municipales. Dichas congregaciones florecieron principalmente en las ciudades de Vic, Olot, Mataró, Tortosa y Barcelona. En total se crearon 35 fundaciones femeninas: 8 hospitalarias, 12 educativas, 13 de ambos campos, 1 claustro-escuela y 1 contemplativa..$^{53}$

\section{LOS INFORMES EPISCOPALES (1800-1867)}

Siguiendo la costumbre inmemorial de la Iglesia, como testimonia el concilio Sardicense del 347 y otros posteriores, los obispos debían de visitar la Sede Apostólica de Roma para venerar las tumbas de los primeros apóstoles Pedro y Pablo (el primero en la basílica de San Pedro del Vaticano y el segundo en la de San Pablo extramuros). También debían entregar un informe detallado al papa y a los dicasterios de la curia romana sobre el estado material y espiritual de sus respectivas diócesis y mantener un encuentro personal con él para comunicarle los asuntos más importantes relacionados con el gobierno de sus diócesis y recibir las instrucciones oportunas. La bula Romanus Pontifex de Sixto IV (1585) estableció que los obispos visitasen Roma cada tres, cuatro, cinco o diez años según la distancia de sus diócesis, y posteriormente en 1740 Benedicto XIV extendió esta obligación a los ordinarios que no eran obispos. ${ }^{54}$

Desde 1725 con Benedicto XIII, el informe de cada diócesis o Relatio se elaboró a partir de un esquema, que consta de nueve capítulos. El primero se refiere al estado material de la santa Iglesia diocesana o metropolitana (la institución, extensión y límites con otras diócesis, los privilegios y prerrogativas históricas de la iglesia, el número de ciudadanos, pueblos, ciudades y aldeas, el estado de la iglesia catedral, monasterios, seminario, hospitales, colegios y monte de piedad). El segundo trata sobre lo relacionado con la diócesis o archidiócesis; el tercero sobre el clero secular; el cuarto sobre el clero regular; el quinto acerca del seminario (número de alumnos y plan de estudios); el sexto sobre las asociaciones, fraternidades y obras piadosas; el octavo sobre las costumbres del pueblo. Y el noveno, se reserva para que el prelado realizara sus propias peticiones a la Santa Sede, referidas principalmente a los problemas más acuciantes de su diócesis.

52 Borràs i Feliu 2006: 38.

53 Yetano Laguna 2000: 161-174.

54 Cárcel Ortí y Cárcel Ortí 1990: 158-160. 
Esta documentación que se conserva en el Archivio Segreto del Vaticano en Roma es sin duda una fuente histórica de primer orden para conocer la vida religiosa de las distintas diócesis, por la gran cantidad de datos que aportan sobre la población tanto eclesiástica como seglar: manifestaciones y prácticas religiosas, transformaciones de la cultura, características de los diversos grupos que integran el conjunto de las diócesis, configuración de los cabildos, clero secular y regular, conflictos y problemas entre éstos, situación económica y reflexiones sugestivas dependiendo de la formación de los obispos y de su celo pastoral. Los informes de los obispos tienen muchas veces un carácter repetitivo y burocrático, variando las informaciones en función del prelado o del procurador que las estructuró, su tono es institucional y las descripciones reflejan muchas veces sus propios intereses..$^{55}$

Para conocer el grado de secularización en Cataluña en el periodo estudiado es importante el punto octavo, "De populi moribus» (acerca de las costumbres del pueblo). Las respuestas de los obispos sirven para hacer una radiografía desde dentro de la Iglesia del avance de la secularización en las diócesis de Barcelona, sede metropolitana de Tarragona, Girona, Lleida, Solsona, Tortosa, Urgell y Vic. Los informes reflejan de algún modo la situación religiosa percibida por cada uno de ellos.

En el primer tercio del siglo XIX los prelados, en su mayoría de ideología reaccionaria, achacan en sus informes la corrupción de las costumbres al nuevo sistema constitucional impuesto, fruto de la libertad de imprenta y sobre todo a la política del Trienio liberal de claro enfrentamiento y persecución de la Iglesia. El contacto con las ideas francesas conduce en su opinión a la secularización y la guerra contra los franceses había introducido nuevas costumbres que desnaturalizaban la forma de ser de los españoles. Por ello reclaman la vuelta al sistema tradicional y el control de la Inquisición de los libros y escritos prohibidos por considerarlos irreligiosos y dañinos para los católicos, especialmente la juventud. Todos ellos participan del mito fernandino presentando al «deseado» Fernando VII como el enviado por Dios para defender la ortodoxia católica, a través de la alianza del trono y del altar. Reacción extremadamente exagerada que algunos obispos matizan al reconocer que la mayoría del pueblo aún era católico y seguía las costumbres tradicionales, siendo pocos los incrédulos contaminados por el veneno de la impiedad.

Los informes de los obispos en el segundo tercio del XIX se hacen eco de la desatención de muchas parroquias durante la guerra carlista, insisten en la necesidad de vigilar estrechamente la educación que reciben los niños en las escuelas y para ello deben controlar los libros escolares. Mantienen los mismos postulados manifestados en la época anterior sobre el control de los libros y la prensa, a través de los cuales se introduce la irreligiosidad e impiedad entre los jóvenes y adultos, y piden el auxilio de las autoridades civiles. Muestran una alerta especial por la expansión del protestantismo y mantienen la vieja idea de que el mundo del espectáculo es por naturaleza inmoral. Son conscientes del avance de la indiferencia religiosa entre los diversos grupos sociales, principalmente en las ciudades, la extensión del divorcio y del concubinato y de la nueva doctrina del socialismo que avanza en los núcleos industriales y en el campo. Protestantismo y socialismo son doctrinas que entran en competición estrecha en el ámbito popular con la Iglesia católica, de ahí la preocupación que muestran los obispos.

\section{Informes de 1800 a 1832}

\section{Barcelona}

En el ámbito de las diócesis catalanas destaca la figura del obispo de Barcelona el aragonés Pablo Sichar (1808-1831). Su episcopalismo se sitúa en una posición equidistante tanto de los liberales puros como del realismo estricto o de la furia contrarrevolucionaria de 1827. Su posición ideológica en la Guerra del francés es claramente antiliberal, como lo demuestra su firma junto a otros obispos catalanes de la Instrucción pastoral de 1812. Durante su ausencia de la diócesis se había refugiado en Mallorca y a su retorno a Barcelona encontró un panorama complejo en cuanto al comportamiento moral de los fieles. Siguiendo el mandato de Fernando VII, impulsó una misión popular en noviembre de 1815 realizada primero entre el clero y otra posterior entre la gente. La misión dirigida a grandes y pequeños tenía como objetivo catequizarlos mediante una pedagogía activa a través de los sermones, oración, rezo del rosario y confesión y comunión general el día de la clausura. Su labor pastoral fue constante y muy activa. Impulsó la educación a través de los colegios religiosos para mejorar la formación religiosa y moral de niños y jóvenes. Vigiló la conducta de los sacerdotes y religiosos, practicó una política más justa de redistribución de las rentas eclesiásticas entre los sacerdotes y las parroquias y utilizó las misiones populares para conseguir la reforma de las costumbres. Denunció la situación irregular de muchas uniones entre hombre y mujer fuera del matrimonio canónico y ordenó a los sacerdotes que utilizasen el poder civil de los alcaldes para evitar la cohabitación de personas que no estuviesen casadas y las relaciones extramatrimoniales. En definitiva, el prelado es consciente de la grave crisis religiosa y moral por la que atraviesa la sociedad barcelonesa a causa de la contienda. ${ }^{56}$

En su informe de 1817 recuerda los abusos cometidos durante la Guerra del francés en algunos monasterios catalanes, cuyos religiosos fueron expulsados de forma violenta. Tras las angustias sufridas y las acciones oportunas llevadas a cabo, las cosas vuelven a la normalidad. Denuncia como mal mayor el haber vivido durante seis años con los franceses, "cum gente alienigena», pero observa en sus visitas pastorales a las parroquias la pervivencia y conservación de la fe íntegra en la mayoría de los fieles. A través de las misiones populares realizadas después de la guerra se ha conseguido erradicar la cizaña sembrada anteriormente, aportando muchos frutos la educación cristiana de niños y jóvenes. También alude al papel de la Inquisición, restaurada tras el retorno de Fernando VII y constata que en las parroquias de la diócesis se mantienen íntegras las devociones tradicionales del rosario, eucaristía y la exposición al Santísimo. En la segunda restauración absolutista Sichar destacó por su 
oposición al movimiento de los agraviados, como se deduce de la Carta Pastoral de $1827 .{ }^{57}$

Al inicio del Trienio liberal en 1820 mantuvo una actitud moderada respecto a la aceptación del régimen liberal, aunque el 8 de abril de 1821 fue arrestado por servil y deportado junto con otros sacerdotes a las Islas Baleares. ${ }^{58}$ Se debe remarcar que durante el trienio fueron asesinados en Cataluña más de setenta eclesiásticos, entre ellos el obispo de Vic Ramón Strauch Vidal (1816-1823), fusilado junto con su secretario Miquel Quetglas cerca de Vallirana el 16 de abril de $1823 .{ }^{59}$

\section{Tarragona}

El arzobispo de Tarragona Romualdo Mon y Velarde reconoce en su informe de 1806 la labor paciente de los párrocos y religiosos de su diócesis en la educación de los fieles. Apenas las costumbres populares han sufrido alteración, más allá de los «vicios» debidos a la fragilidad humana. ${ }^{60}$ En 1808 formó parte de la Junta revolucionaria que dio paso a la Junta Corregimental. Se mantuvo al frente de la diócesis hasta el otoño de 1809 y después se refugió en Mallorca hasta el final de la guerra. En 1814, de acuerdo con el decreto real, el prelado publicó la pastoral L'origen, resultas y fi desastrat de la corrupción dels costums, en la que fustiga la desviación religiosa y moral de los españoles tras la guerra y exalta la figura angelical de Fernando VII. La contienda había dejado una estela de cambios en las costumbres que desnaturalizaban la forma de ser de sus fieles. El origen de la impiedad se debe a la corrupción de costumbres, fruto de la negación de la existencia de Dios, y como consecuencia la satisfacción de todos los vicios e inmundicias. ${ }^{61}$ En 1815 el prelado recibió la Gan Cruz de Carlos III y al año siguiente fue nombrado arzobispo de Sevilla.

Los males que sufrió la ciudad de Tarragona durante la ocupación napoleónica fueron numerosos, máxime tras el sitio y asalto del 28 de junio de 1811. La actitud de varios miembros del cabildo catedralicio fue ejemplar, destacando sobre todo la figura del canónigo Ignasi Ribes que ayudó a que la represión ciudadana disminuyera e incluso consiguió en febrero de 1813 convencer al general Bertolletti que no abriera sus puertas la logia francmasónica situada en el convento de religiosos carmelitas descalzos de la ciudad. ${ }^{62}$

Durante el Trienio liberal y años posteriores se constata en la diócesis de Tarragona una disminución del cumplimiento pascual, como se desprende de las anotaciones del párroco de Barberà de la Conca, a pesar de las exhortaciones, súplicas y amenazas que había hecho en este sentido la autoridad municipal. ${ }^{63}$

\footnotetext{
57 Archivio Segreto Vaticano (ASV). Congregatione de Concilio, Relationes Diocesium (fine sec. XVI-1908). Visita ad Sacra Apostolorum Limina (V. A. S. A. L.), Barcilonen 111B: 1817.

58 Gil Novales 2010: vol. 3, 2881.

59 Figuerola 1988: 102 y 115 . Strauch publicó el 14 de octubre de 1820 un edicto en el que prohibía todos los libros, folletos, impresos, pepeles mansucritos, retratos, estampas y figuras obscenas que habían sido desautorizadas por el Índice o que atacaban a la religón católica.

60 ASV, V. A. S. A. L., Tarraconen 785 B, 21 diciembre 1806.

61 Fuentes, Quijada y Sánchez 2012: 13; Barbastro Gil 2013: 102; Gil Novales 2010: vol. 2, 2021.

62 Fuentes, Quijada y Sánchez 2012: 272-273; Moliner Prada 2011: 281-286.

63 Perea 1993: 75
}

Lleida

La diócesis estuvo gobernada por los obispos Jerónimo María de Torres, Simón de Rentería y Reis y Pablo Colmenares. Jerónimo María de Torres (1783-1816) en la Guerra de la Convención (Guerra Gran en la denominación catalana) publicó el Edicto, mandando hacer rogativas por la victoria de nuestras armas en la guerra contra Francia (Lérida, 1793). En la Relación de 1805 reconoce que las costumbres de sus fieles permanecen intactas. Situación que cambió radicalmente tras el trauma que sufrió la ciudad y su diócesis con la ocupación francesa de 1808. Presidente de la Junta Superior de Cataluña que se constituyó en la ciudad del Segre en junio de 1808, personaliza la resistencia de la ciudad contra los franceses junto con la cúpula eclesiástica ilerdense. De ideas absolutistas, piensa que el programa francés introduce un proceso de secularización de la sociedad en todos los sentidos, significaba el fin de los privilegios eclesiásticos, la desamortización de sus tierras y el declive de su influencia y preeminencia de la institución eclesiástica. ${ }^{64}$

Simón de Rentería y Reis era de ideología absolutista. En 1812 tradujo la célebre obra del Abate Barruel, Compendio de las memorias para servir a la historia del jacobinismo (Villafranca del Bierzo) y en 1815 publicó el opúsculo Filosofía de la religión contra los sistemas de los impios (Santiago de Compostela). Nombrado obispo de Lleida en 1819, publicó un Edicto dirigido a los eclesiásticos para que no se vistan de paisanos (1820). Fue uno de los obispos expulsados por orden del gobierno el 13 de febrero de 1823 tras publicar un edicto contrario a los decretos de las Cortes, en el que afirmaba que el régimen liberal era incompatible con la religión. ${ }^{65}$ La prohibición de predicar los sermones de Cuaresma en varias parroquias a diversos sacerdotes de tendencia liberal motivó que el Ayuntamiento de Lleida solicitase su expulsión a la Diputación. ${ }^{66}$

Desde el principio se opuso férreamente a través de diversos documentos que dirigió a las Cortes a su política eclesiástica, realizada sin el consentimiento de Roma. Siempre mostró su apoyo a la monarquía tradicional y a la alianza del trono y del altar, por lo que fue condecorado con la Gran Cruz de Carlos III y elegido en 1824 arzobispo de Santiago. Su actuación antiliberal le llevó a buscar el apoyo del papa Pío VII del que obtuvo su confirmación. ${ }^{67}$ En cuanto a las costumbres del pueblo leridano, resalta el obispo que el cambio revolucionario no impidió a los buenos cristianos mantenerse fieles a las enseñanzas de la Iglesia, salvo los «malos» que habían abandonado la religión. Para luchar contra la difusión de los libros prohibidos no dudó en publicar un edicto «con motivo de la inundación de los malos libros impíos, heréticos y lascivos y las estampas impúdicas» y obligó a denunciar a quienes los tuviese o propusiera discursos contrarios a la moral, dogmas y

64 Sánchez Carcelén 2012: 28-29; Gil Novales 2010: vol. 3, 3012.

65 Colección de oficios y representaciones que desde el año 1820 ha dirigido el obispo de Lérida al Gobierno y Cortes Ilamadas Constitucionales reclamando contra sus decretos en materias eclesiásticas, y publica para la instrucción del clero y pueblo de su diócesis, Lérida 1823. Cf. Sánchez Carcelén 2012: 173; Gil Novales 2010: vol. 3, 2564; Ritzler y Sefrin 1968: vol. VII.

66 Sánchez Carcelén 2012: 206; Gil Novales 2010: vol. 3, 2564.

67 Sánchez Carcelén 2012: 183. 
derechos de la Iglesia. Por ello pidió la restauración de la Inquisición y la censura, para castigo de los «delincuentes, freno a sus lenguas y a sus plumas». ${ }^{68}$

En su informe de 1824 hace un balance de la situación anterior al estallido de la Revolución de 1820 y los cambios introducidos, y describe con todo detalle en su Memoria el calvario que sufrió tras su expulsión de la diócesis. En las visitas que había realizado a los pueblos de montaña en 1819, a punto de estallar la revolución, se dio cuenta de que la mitad de los feligreses no asistían a la misa de los domingos por su ocupación con los ganados, por lo que concedió a los sacerdotes el poder celebrar dos misas. Consciente de que el sacramento de la extremaunción no se administraba en vida a los enfermos y frecuentemente se llegaba tarde, propuso realizarlo tres días después de viaticar al enfermo. A partir del 5 de julio de 1822 el prelado apenas salía de su casa para ir a la Iglesia a causa del peligro que corría, por lo que interrumpió las visitas a las parroquias tal como tenía programado. El gobierno revolucionario le espiaba con agentes todos sus pasos, lo miraban como un obispo perjudicial para la construcción de un sistema «impío y antisocial» que había llevado a mal los oficios y representaciones que había hecho a las Cortes y al Rey en defensa de los derechos de la Iglesia y de la religión.

Los agentes de la revolución pretendían que los obispos cubriesen con el manto de la religión todas sus maquinaciones dirigidas principalmente a la destrucción del catolicismo y confundir lo sagrado con lo profano, convirtiéndolos en instrumentos de sus planes infernales. Cada día iba creciendo el desprecio y persecución de la religión y de sus ministros, y apenas se podía dar un paso sin oír las mayores blasfemias y sufrir algún insulto de parte de los militares constitucionales y de la milicia voluntaria. Por esta razón «no salía de casa sino a la Iglesia desde el 5 de julio de 1822 hasta las 5 de la mañana del 13 de febrero de 1823 en que fui desterrado de esa ciudad y obispado por la facción revolucionaria de la ciudad de Barcelona que se había distinguido por su suma exaltación e impiedad $"{ }^{69}$ Encerrado en la Ciudadela, consiguió salvar su vida gracias a la acción decidida de dos alcaldes constitucionales de la ciudad y pudo embarcar hacia Málaga y regresar a Lleida en noviembre.

Simón de Rentería y Reis piensa en 1824 que todavía hay buenos cristianos y costumbres de bien en Lleida, a pesar de la persecución sufrida y la impunidad del gobierno frente a la propaganda irreligiosa que inundaba todas partes. La segunda restauración de Fernando VII posibilitó en la diócesis leridana el esplendor de la religión y el incremento de la religiosidad de los fieles apoyada por los sacerdotes y religiosos y las célebres misiones populares. Florecieron de nuevo los novenarios, los libros de oraciones y las estampas y cantos navideños que proporcionaba la imprenta Bonaventura Coromines, así como las actividades de las congregaciones religiosas (La Sangre, los Dolores, San Salvador y la de los Labradores). Fueron numerosos los actos religiosos de carácter reparador que se celebraron en las parroquias para recuperar los valores religiosos ultrajados. ${ }^{70}$

\footnotetext{
68 ASV, V. A. S. A. L., llerden 399 B, 30 abril 1824: 217

69 ASV, V. A. S. A. L., llerden 399 B: 1824: 210-210v.

70 Sánchez Carcelén 2012: 219 y 220.
}

El obispo Pablo Colmenares (1825-1832) actuó en la misma línea que su predecesor, con medidas severas frente a la difusión de los libros prohibidos por la Iglesia ${ }^{71}$, aunque tuvo que mantener un espíritu conciliador frente al problema surgido con el levantamiento de los «agraviados» en 1827. Se opuso a liberales y realistas que conspiraban o empleaban las armas contra Fernando VII y proclamó los supremos valores de la religión, el rey, el reino y la patria. ${ }^{72}$ Eran tiempos de calamidad a causa de las pasiones humanas, al romperse el freno de la subordinación y de la obediencia sobrevino la inestabilidad y la división de los cristianos y monárquicos. En su informe de 1826 recuerda que el hombre solo ve lo externo y Dios en cambio ve el corazón de los hombres. Su propósito es renovar la piedad y las devociones de los feligreses diocesanos por lo que deben frecuentar los sacramentos y ser virtuosos. ${ }^{73}$ En la pastoral Sobre la dignidad real, su potestad suprema, y obediencia a los reyes y a su gobierno (1828) concluye que todos los españoles son católicos realistas, los demás son anarquistas (no españoles). ${ }^{74}$

\section{Girona}

La diócesis de Girona estuvo dirigida por los obispos Juan Miguel Pérez González y Dionisio Castaño y Bermúdez. Tras la restauración de Fernando VII Juan Miguel Pérez González (1819-1824) mantuvo una actitud pragmática. Ni se manifestó proclive al absolutismo, ni adoptó una postura de oposición al Trienio liberal. En este caso intentó apaciguar el enfrentamiento del gobierno liberal con la Iglesia diocesana y sus actitudes anticlericales. Siguiendo las órdenes gubernamentales envió varias circulares a los párrocos en las que les exhortaba a obedecer al poder civil. En la pastoral de 15 de enero de 1821 sobre libros prohibidos, habla de que va a establecer un tribunal eclesiástico, en sustitución de la Inquisición, para juzgar a los contraventores; en la de 16 de mayo del mismo año insiste en la obediencia; y en la de 26 de mayo de 1822 ataca duramente a los facciosos y a cuantos se oponen al sistema establecido. Se dice de él que carece de energía, quizás por su mala salud constante. ${ }^{75}$

Dionisio Castaño y Bermúdez (1825-1834) en su informe de 1829 destaca las buenas costumbres de sus fieles que acuden regularmente a los oficios litúrgicos de las iglesias y mantienen las costumbres cristianas como norma. ${ }^{76}$ En la primera guerra carlista algunos párrocos abrazaron su causa y otros, como el domero de Olot, Dr. Osona, tuvieron que dejar la parroquia por su adscripción liberal. Parece que solo dos sacerdotes tomaron las armas en esta guerra, que afectó sobre todo a la comarca de la Garrotxa. ${ }^{77}$

\section{Vic}

La diócesis de Vic estuvo gobernada por los obispos Francisco de Veyan y Mola y Pablo Jesús Corcuera y

\footnotetext{
71 Carta pastoral sobre prohibición de libros, Lérida, 20 julio 1825.

72 Sánchez Carcelén 2012: 295.

73 ASV, V. A. S. A. L., llerden 399 B: 1824: 267.

74 Gil Novales 2010: vol. 1, 751.

75 Marqués 2002: 599; Arnabat Mata 2004: 263-278; Gil Novales 2010: vol. 3, 2389; Ritzler y Sefrin 1968.

76 ASV, V. A. S. A. L., Gerunden 363 B, 1 octubre 1829: 67-67v.

77 Marqués 2002: 601.
} 
Caserta. Francisco de Veyan y Mola (1784-1815) mantuvo en tiempos de tanta calamidad una actitud decidida frente a la ocupación napoleónica, no abandonó a su rey, incluso cuando la ciudad fue ocupada, y rechazó taxativamente la prestación de fidelidad a Napoleón. ${ }^{78}$ En la Pastoral de 23 de julio de 1808 contrapone a España con Francia, lo español y lo francés, Fernando VII y Napoleón, la católica España y la atea Francia, e invita a los eclesiásticos y fieles a colaborar con donativos y oraciones en la defensa de la religión, la patria y el soberano rey amenazado. ${ }^{79}$ Fiel al absolutismo, se le puede considerar regalista moderado. Se opuso al decreto de las Cortes de Cádiz de abolición de la Inquisición (febrero de 1813) y se negó a publicarlo en la diócesis.

Veyan cree que el pueblo estaba fuertemente adherido a la fe y a la Santa Sede Apostólica, y era devoto y obediente a su autoridad. A través de sus circulares y pastorales no se deduce que los feligreses abandonaran la práctica religiosa, en su mayoría cumplían los preceptos de confesión y comunión. Lo más difícil era el conocimiento de la doctrina católica, quizás por la apatía de algunos párrocos, que llevaban a determinados fieles a la apatía y el desinterés. En su Informe de 1802 remarca que los fieles no tienen costumbres «depravadas» y para evitar la laxitud se realizan misiones populares por todos los pueblos. Las asociaciones católicas están muy arraigadas, entre ellas la de San Felipe Neri y la de S. Vicente Paúl. ${ }^{80}$ En su informe de 1814 recuerda Veyan que toda la diócesis quedó perturbada durante la contienda, no pudiendo realizar las visitas a las parroquias y administrar las ordenaciones sacerdotales, y se opuso por todos los medios a la difusión de las ideas francesas. Es consciente de las corruptelas introducidas en las costumbres por el régimen militar impuesto, a través de la prensa e impresos y la supresión de la Inquisición, y reafirma la conservación de la fe y subordinación a la Iglesia por parte de la mayoría del pueblo, opuesto a la irreligión y a la impiedad. Tan solo observa una disminución del precepto pascual por parte de algunos fieles y en la frecuencia de los sacramentos. Todo su esfuerzo está dedicado a conseguir la reforma de las costumbres. La actitud mostrada por el obispo recibió los elogios del secretario de la Congregación vaticana por el testimonio público que dio ante el poder del Imperio francés al que no se sometió. ${ }^{81}$

Valentí Girbau destaca del obispo Veyan su austeridad y rigor personales, su mensaje reformista (no jansenista), preocupado por el buen funcionamiento de las parroquias y la ejemplaridad de los eclesiásticos en el ejercicio de su ministerio. Su espíritu ilustrado le impulsó a crear la Biblioteca Episcopal (1806) y a reformar los estudios académicos del Seminario de Vic. ${ }^{82}$

Pablo Jesús Corcuera y Caserta (1825-1835) se refiere en su informe de 1828 a la revuelta de los agraviados o «malcontents» iniciada en Cataluña el año anterior. El levantamiento contra los liberales se hizo en nombre de la religión y del rey: «Vivat Religio, vivat Rex, pereant Masones et Negri» (Viva la Religión, viva el Rey, mueran los Masones y los Negros). Aunque señala que en su diócesis los

\footnotetext{
78 Ramisa Verdaguer 1995: 287.

79 Moliner Prada 1997: 21-22.

80 ASV, V. A. S. A. L., Vicen 869 B:1802.

81 ASV, V. A. S. A. L., Vicen 869 B, 13 agosto 1814.

82 Girbau 1992: 357-368; ibídem: 1996.
}

liberales («negros») o constitucionales no eran muchos, se agrupaban en sociedades secretas, adscritos a la masonería y comunería. El modelo a seguir era el levantamiento de 1808 contra Napoleón. Son tiempos difíciles, de naufragio para la fe católica y las costumbres. Denuncia los abusos y sacrilegios que se cometieron en medio de la revuelta en numerosas iglesias de la diócesis, entre ellas Sta. María de Besora, Sant Romà de Sau, Sant Hipòlit de Voltregà, Sta. Coloma de Centelles y Sant Fruitós de Castellterçol. Con este motivo envió una circular a los párrocos y regentes para que conservaran bien escondidas las llaves del sagrario de las iglesias, en su misma habitación donde vivían, y cerraran todas las puertas y ventanas del recinto sagrado. ${ }^{83}$

\section{Informes de 1833 a 1867}

\section{Barcelona}

El obispo de Barcelona Pedro Martínez San Martín (1832-1849) en su informe de 1839, presentado en la ciudad del Vaticano por el archidiácono de Trujillo Salvador Borrell, alude a los grades acontecimientos que se produjeron en esta ciudad el 25 de julio de 1835, el incendio de conventos, la persecución del clero y el asesinato del capitán general Bassa. Las autoridades dejaron hacer. Hermano de un general liberal, colaboró con los gabinetes liberales de la regencia de María Cristina. Senador por Barcelona en 1837 y más tarde senador vitalicio, Gregorio XVI lo nombró prelado doméstico (1839). El obispo señala en su informe que el ambiente de la ciudad ha vuelto a la normalidad al final de la contienda, cuestión que pone en duda el capuchino F. F. de Alcaraz según consta en el resumen de la relación, quien duda de la inteligencia del obispo y le sorprende que hubiera llegado a un cargo de tanta responsabilidad. ${ }^{84} \mathrm{EI}$ prelado mantuvo una buena amistad con los obispos Fèlix Amat de Palau y Font y su sobrino, Fèlix Torres Amat. Por su actuación política y gobierno de su diócesis la curia romana lo clasificó como liberal y jansenista. Se mostró favorable en sus pastorales a aceptar el régimen liberal, entre ellas destaca la de marzo de 1838 que fue impugnada por diversos escritos. ${ }^{85}$

Su sucesor en la diócesis el obispo Josep Costa i Borràs (1850-1857) se mostró intransigente con las nuevas corrientes liberales progresistas del Bienio progresista (1854-56) y se tuvo que exiliar en Cartagena. Se enfrentó con el capitán general Ramón de la Rocha por clausurar la Escuela de la Virtud (escuela de catequesis para obreros en la parroquia barcelonesa de San Agustín), bajo la acusación infundada de haber incitado a la huelga de obreros de1855. Promovió la cristianización del pueblo mediante las misiones populares y la enseñanza del catecismo (publicó como se ha indicado uno bilingüe catalán-castellano que fue reeditado hasta bien entrado el siglo $\mathrm{XX}$ ) y reorganizó los institutos religiosos. Su carácter rigorista e intransigente en cuestiones religiosas fue motivo de polémica en la prensa liberalprogresista (La Actualidad, La nación, El constitucional, El barcelonés, El Sol) y de varios conflictos con sectores de la

83 Ídem: 13 marzo 1828

84 ASV, V. A. S. A. L., Barcilonen 111B, 9 enero 1839.

85 Martínez San Martín 1839. Citado en Martí Bonet 2006: 283. 
ciudad de Barcelona. Defendió la unidad católica de España en su obra Observaciones sobre el presente y porvenir de la Iglesia en España (Barcelona, 1856), y siempre negó su vinculación con el carlismo, frente a las críticas constantes de la prensa. ${ }^{86}$

Costa i Borràs en una carta dirigida al ministro de Gracia y Justicia en julio de 1851, en respuesta a las denuncias hechas contra la predicación de las misiones populares, por una supuesta intromisión política, reclamó la colaboración del poder eclesiástico y civil para reformar las costumbres paganas y las doctrinas disolventes muy extendidas en Barcelona. En dicha carta utiliza una frase antológica: «No veo más remedio que religión y represión». ${ }^{87}$

En su informe de 1857 pide cautela a sus sacerdotes por la inestabilidad política que vive el país y arremete contra quienes trasmiten a través de sus escritos ideas equivocadas o heréticas y vilipendian la autoridad de los obispos. Este tipo de publicaciones (libelos, anónimos, etc.) producen gran escándalo entre los fieles y el pueblo en general al excitar sus pasiones. Costa i Borràs había criticado el protestantismo en una Exhortación pastoral (1853) argumentando que la moral de los protestantes está fabricada a medida del gusto de cada uno. ${ }^{88}$

El obispo Antoni Palau i Termens le sucedió al frente de la diócesis entre 1857 y 1862. Periodista brillante que dirigió la Revista Católica (1842), de información general de la Iglesia, participó en la fundación de la Librería Religiosa de Barcelona. Mantuvo una actitud atenta a las transformaciones económicas y culturales que la ciudad industrial de Barcelona iba experimentando y a los problemas religiosos. Intentó cohesionar a todos los fieles e instituyó las conferencias eclesiásticas. ${ }^{89}$ En su informe de 1862 el prelado se hace eco de que en una ciudad como Barcelona tan abierta al comercio, negocios y lenguas diversas, había penetrado una forma de vida contraria a lo espiritual, difundiéndose doctrinas falsas, costumbres depravadas, prostitución, insidias y sobre todo la indiferencia. ${ }^{90}$

También Pantaleón Montserrat Navarro, obispo de Barcelona entre 1863-1870, insiste en su informe de 1867 en parecidas ideas. En una ciudad con tantos espectáculos, se pervierten las costumbres del pueblo y los hombres llegados de todas las partes introducen doctrinas erróneas. La tolerancia impuesta permite todo: prostitución, blasfemias, juego en los casinos, etc. ${ }^{91}$

\section{Tarragona}

El obispo Josep Costa i Borràs ocupó entre 1857 y 1864 la sede del arzobispado de Tarragona. Se ocupó especialmente del clero y creó en 1860 una publicación quincenal, precedente del Boletín oficial del arzobispado de Tarragona. Fue un defensor a ultranza de los derechos y prerrogativas de la Iglesia católica frente al liberalismo. ${ }^{92}$ En su informe de 1862 señala que el objetivo prioritario de su visita a los

\footnotetext{
86 Martí Bonet 2006: 289.

87 Figuerola, Martí y Raguer 2005: 134.

88 Costa y Borrás 1853.

89 Martí Bonet 2006: 290-291.

90 ASV, V. A. S. A. L., Barcinonen 111B, 11 julio1862: 348.

91 Ibídem: junio 1867: 371.

92 Martí Bonet 2006: 289-290.
}

pueblos de la archidiócesis es fomentar la piedad religiosa y las virtudes entre los fieles a través de libros piadosos, escritos y las misiones populares. Hay que estar alerta porque la libertad puede introducir el error y los vicios en el pueblo cristiano, aún más el indiferentismo creciente en las ciudades. Gracias a Dios - manifiesta - que en los pueblos la religión se conserva y sostiene con más firmeza. La labor de los sacerdotes es primordial para inculcar en el pueblo los principios religiosos. ${ }^{93}$

Su sucesor el obispo Francesc Fèlix i Solans (1864-1870) recuerda en su informe de 1867 que son tiempos recios y difíciles, porque las leyes permiten en nombre de la libertad que las buenas costumbres se corrompan. El mal acecha por doquier. Como respuesta propone conservar la integridad de la fe de acuerdo con las obras, la difusión de pastorales y exhortaciones para elevar la religiosidad del pueblo, publicar libros para educar a los jóvenes, la celebración de misiones populares en las parroquias e invitar a los laicos a realizar ejercicios espirituales. En definitiva, llevar la instrucción religiosa a los jóvenes a través de las pías congregaciones marianas y su educación a través de escuelas dominicales vespertinas. ${ }^{94}$

\section{Vic}

Antoni Palau i Termens, obispo de Vic entre 1854-1857, en su informe de este último año constata como otros obispos que viven en tiempos de calamidad manifestada por la indiferencia religiosa que se observa en todos los grupos sociales y por la depravación de las costumbres. Ante ello propone incrementar la educación entre los jóvenes, las prácticas de piedad y los sacramentos. ${ }^{95}$

Su sucesor en esta diócesis el prelado Joan Josep Castanyer i Ribas (1858-1865) en su informe de 1861 afirma al contrario que las costumbres de los fieles en líneas generales no son malas. En su visita a las parroquias observa que son pocos los que no cumplen los preceptos anuales de la confesión y comunión pascual, y aunque algunos se han contaminado con los efectos de la civilización moderna, no se cometen abusos como la costumbre perversa de la cohabitación de hombre y mujer fuera del matrimonio canónico. ${ }^{96}$

\section{Lleida}

En la diócesis de Lleida el obispo Pedro Cirilo Úriz Labayru (1850-1861) reorganizó la diócesis, tras los años de ausencia desde 1837 del obispo Julián Alonso, acusado de haber colaborado con la Junta corregimental carlista establecida en Àger. Entre 1848 a 1850 estuvo bajo el gobierno del obispo Josep Costa i Borràs. Úriz incrementó la presencia e influencia de la Iglesia, fundó el Boletín Eclesiástico del Obispado de Lérida, reorganizó el seminario y apoyó la creación de la Congregación de Carmelitas Misioneras Teresianas del padre Palau. Consciente de la creciente pérdida de influencia de la Iglesia en la sociedad,

\footnotetext{
93 ASV, V. A. S. A. L., Tarraconen 785 B, 30 mayo 1862

94 Ibídem: 14 mayo 1867.

95 ASV, V. A. S. A. L., Vicen 869 B, 28 octubre 1857.

96 Ibídem: 13 oct. 1861.
} 
intentó consolidar la presencia pública de la religión católica y frenar los focos de anticlericalismo en Lleida. Se presenta como legitimador político del régimen y mediador social. ${ }^{97}$ En su informe de 1857 reconoce que el pueblo en general es bueno y fiel aunque una minoría no cumple los preceptos divinos y de Pascua (confesión y comunión una vez al año). Algunos no respetan los días festivos por sus negocios y quehaceres y otros observan los preceptos de la fe por el miedo. Exhorta a sus fieles a que no lean libros prohibidos y evitar el escándalo a los jóvenes, que deben recibir educación cristiana en las escuelas civiles y conventuales. Similares reflexiones aparecen referidas en el informe de 1861: pueblo piadoso y religioso, que contribuye a las necesidades económicas de la Iglesia; exhortación a la obediencia, práctica de la oración, escuchar la palabra de Dios y recibir la eucaristía; y sumo cuidado con los escritos liberales perniciosos. ${ }^{98}$

Su sucesor el obispo Marià Puigllat i Amigo (1862-1870) continuó la política renovadora. Trabajador infatigable, seguidor del tomismo, introdujo en el Seminario el modelo que había impuesto anteriormente en Vic, en cuanto a los aspectos pedagógicos, organizativos y de gestión. ${ }^{99}$ Los problemas de orden que se producían en la misa del gallo en muchas iglesias fue motivo para que el prelado cambiase en 1863 el horario de la misa en la catedral, trasladada al amanecer del día veinte y cinco de diciembre sin cantos de villancicos. En 1862 impulsó la creación de la Academia Bibliográfico-Mariana con el objetivo de difundir los valores del catolicismo a partir de la actividad cultural para propagar libros y escritos relativos a la Virgen. Dos años después tenía la Academia 1.322 socios en toda España, principalmente en Navarra (224), Lleida (183) y Valencia (185). Crecieron también las asociaciones religiosas como las Misioneras esclavas del Corazón de María (1862) y las Hermanas de los Pobres (1864)..$^{100}$

En su informe de 1867 el prelado insiste también en las mimas ideas de su predecesor: el pueblo leridano es religioso aunque algunos no cumplen con los preceptos divinos y de la Iglesia y solicita el apoyo de las familias a los párrocos. ${ }^{101} \mathrm{Y}$ en el Boletín Oficial Eclesiástico de la Diócesis de Lérida (marzo 1867) se lamenta de la inmoralidad e irreligión de «nuestros días».

\section{Girona}

De la diócesis de Girona solo consta el informe de $1866 \mathrm{del}$ obispo Constantí Bonet (1862-1875) en el que destaca sobre todo la religiosidad del pueblo, las numerosas asociaciones religiosas existentes en las parroquias bajo la advocación de la Virgen o del Sagrado Corazón de Jesús y la práctica de las misiones populares. Un punto central es su dedicación al seminario y como prueba de ello aporta un pequeño opúsculo de su autoría titulado Estatutos para los alumnos externos del Seminario tridentino de la ciudad de Gerona

\footnotetext{
97 Closas Salinas 2015: 673-715; ibídem 2004: 381-412.

98 ASV, V. A. S. A. L., llerden 399 B, octubre 1856 y 1 diciembre 1861:

99 Roviró Alemany 1998: 213.

100 Pons i Altet 2005: 229-230.

101 ASV, V. A. S. A. L., llerden 399 B, 30 mayo 1867: 346-347.
} 309.
(30 julio 1864). Trata de inculcar en los seminaristas el buen comportamiento y les prohíbe taxativamente asociarse con jóvenes disolutos, asistir a los bailes, cafés, teatros, así como la entrada en las casas de juego y de cualquiera otra que pueda infundir la mera sospecha (artículo 20). ${ }^{102}$

\section{Tortosa}

El único informe de esta diócesis corresponde al obispo Benet Vilamitjana i Vila de 1867. En él constata el prelado que salvo excepciones la mayoría de fieles son tenaces y buenos cristianos. Recuerda los efectos nocivos que tuvo en la diócesis la guerra carlista, llamada de los siete años (1833-1840). Trastocó la vida de los pueblos, los niños abandonaron las escuelas y la instrucción religiosa y todo fue muy superficial en aquel tiempo en el que se generaron diversos escándalos. Se difundió entre el pueblo sencillo campesino doctrinas contrarias a la fe, las costumbres y las autoridades eclesiásticas. Los ministros de la religión deben de velar para evitar la propagación de esta peste. ${ }^{103}$

\section{La Seu d'Urgell}

En la diócesis de la Seu d'Urgell sobresale la figura del obispo Josep Caixal i Estradé (1853-1879) que dio un impulso al seminario diocesano y a las actividades sociales y culturales entre los sacerdotes, laicos y niños. La construcción de un nuevo seminario, con rango de institución académica superior, para una mejor formación de los aspirantes al sacerdocio, reafirmó el papel dirigente de la Iglesia en una diócesis muy extensa y pobre donde los servicios del Estado eran mínimos. En cuanto a los proyectos sociales, promocionó la canalización del rio Segre, la creación de un banco agrícola y una casa de caridad.

En su informe de 1858 Caixal recuerda que el pueblo se ha mantenido firme en la fe y a la Sede Apostólica hasta que la Revolución de 1820 perturbó la situación. La prensa y la libertad sin límite alguno han provocado una crisis religiosa que los obispos han frenado mediante las misiones populares y la práctica de los sacramentos por parte de los fieles. Solo la diligencia, la práctica de las virtudes y los ejercicios espirituales han conseguido mantener al pueblo fiel. En su informe de 1862 ratifica el prelado que los dos problemas fundamentales que inciden en las costumbres cristianas son el protestantismo y el socialismo difundido a través de la prensa.

En su informe de 1867 se refiere al Valle de Andorra y a su pueblo fiel y cristiano que ha sucumbido por la llegada de españoles de todas las facciones. Estos han corrompido la fe y las costumbres e introducido ideas revolucionarias. El talante de este obispo, militante activo del carlismo, le llevó a buscar los remedios más prácticos para combatir las ideas liberales, las misiones populares y las asociaciones apostólicas entre ellas el Apostolado de la Oración. ${ }^{104}$

\footnotetext{
102 ASV, V. A. S. A. L., Gerunden 363 B, 30 setiembre 1866.

103 ASV, V. A. S. A. L., Derthusen 291, mayo 1867: 275 v. Sobre su actuación véase Ibáñez Gisbert 1991.

104 ASV, V. A. S. A. L, Urgelen 840, 20 enero 1858, 1862 y abril 1867.
} 


\section{CONCLUSIONES}

Como se ha podido comprobar en los informes de los obispos, a todos ellos les guió el afán reformador de las costumbres del pueblo y del clero. La mayoría del episcopado piensa que el pueblo en general es piadoso y buen cristiano, aunque también reconocen su escasa cultura religiosa y la necesidad de una formación sólida en la doctrina cristiana. Cada prelado presenta su acción pastoral adecuada a la realidad de cada diócesis.

Las autoridades eclesiásticas en cada una de las coyunturas políticas, sobre todo en los periodos de las dos restauraciones fernandinas y durante los gobiernos liberales moderados (1844-1854) exigen de las autoridades civiles su apoyo para reformar las costumbres contrarias a la moral católica. Algunos, como Pablo Sichar y Pablo Colmenares mantienen una actitud equidistante entre liberales y realistas.

Los informes episcopales hacen una apelación constante a la circulación de malos libros en las ciudades y a la necesidad de evitar que caigan en manos de los jóvenes y de los fieles en general. La mala prensa (liberal) y los libros impíos y todo tipo de propaganda irreligiosa son la causa principal de la impiedad y de la corrupción de costumbres. Algunos obispos identifican ciudad con libertad, corrupción e irreligión. Desde comienzos del siglo las pastorales de los obispos aluden con frecuencia a las injurias dirigidas a los clérigos y religiosos, desprecio de las actuaciones del papa y obispos, ultrajes a las prácticas religiosas, objeto de befa en pasquines, folletos y en determinada prensa de corte anticlerical, sobre todo en los períodos álgidos de la Revolución liberal (1810-1813, $1820-23,1834-43$ y 1854-56). El impacto de la Revolución de 1820 dejó una impronta general en el episcopado, como recuerda el obispo de la Seu d' Urgell Josep Caixal i Estradé o el de Vic Pablo Corcuera y Caserta, por los abusos y sacrilegios que se cometieron en algunos pueblos.

La pérdida de consideración de la Iglesia como institución y la desacralización progresiva de los «ministros de la religión» se percibe en los informes de los obispos de Cataluña a partir del Trienio liberal. La confusión de lo sagrado con lo profano, como señala Simon de Rentería y Reyes (obispo de Lleida, 1824), es un punto central en las comunidades de ámbito campesino para preservar las competencias de la Iglesia en el ámbito religioso frente a la intromisión del gobierno liberal revolucionario. Tras el Trienio liberal se observa en general la disminución del cumplimiento del precepto pascual entre los fieles de las diferentes diócesis, incluso en aquellas como Tarragona y Vic que conservaban esta práctica anteriormente.

La indiferencia y apatía religiosa se manifiesta por doquier durante el periodo isabelino, fruto de la contaminación con el mundo moderno, la «vida mundana» o mundanización, tan alejada de los valores evangélicos. Barcelona, puerto de mar, abierta al mundo y a otras culturas, es un buen ejemplo de ello según su obispo Antoni Palau i Termens, quien señala que el fenómeno de la indiferencia religiosa también afecta a todos los grupos sociales en la diócesis de Vic. Por su parte Josep Costa i Borràs remarca que la indiferencia religiosa también crece en las ciudades de la diócesis de Tarragona mientras se conserva con firmeza la religión en los pueblos.

Los acontecimientos políticos derivados del proceso de la Revolución liberal influyeron de forma directa o indirecta en la cuestión religiosa y en el pueblo. La Iglesia, alterada de forma radical por los cambios sufridos, se vio obligada a través de sus pastores a imaginar nuevas estrategias que muchas veces se limitaron a radiografiar lo que consideran negativo para la institución y su misión pastoral. Todos los prelados lamentan la pérdida de valores cristianos, el aumento de actitudes hostiles y anticristianas. Las nuevas corrientes de pensamiento, liberalismo, socialismo, materialismo y masonería, son para la mayoría de ellos las causas del debilitamiento progresivo y alejamiento de las prácticas religiosas de los fieles, de la corrupción de costumbres, del anticlericalismo y secularización creciente.

Y ante la decadencia de la religión y la moral católicas los obispos proponen idénticos remedios: campañas contra las manifestaciones de inmoralidad; el matrimonio católico frente al divorcio y el concubinato; la recepción de los sacramentos y el fomento de la piedad y cultos al Sagrado Corazón, a la eucaristía y a la Virgen; la creación de asociaciones católicas, congregaciones marianas, escuelas dominicales y colegios religiosos; la práctica de las misiones populares que habían dado cuantiosos frutos y la educación de los jóvenes; la predicación y la catequesis, de ahí la importancia de la edición del catecismo en lengua catalana de Josep Costa i Borràs; el fomento de las bibliotecas parroquiales y el apoyo a la familia cristiana.

Entre los vicios señalados en los informes episcopales con más reiteración encontramos el incumplimiento dominical, la no observancia del ayuno y abstinencia y el precepto pascual, la lujuria y la blasfemia. El protestantismo aparece como un problema crucial para la Iglesia en la segunda mitad del siglo en el informe del obispo de Barcelona Josep Costa i Borràs de 1851. En las ciudades fabriles de Cataluña los obispos constatan el retroceso de la religión entre los obreros. Josep Caixal i Estradé plantea como problema fundamental en 1862 el socialismo junto al protestantismo. El socialismo anticristiano podía seducir a los obreros, junto a la escuela laica y las logias masónicas.

A medida que avanza el proceso de secularización y la pérdida del poder económico y político de la Iglesia, relegada a su dimensión espiritual, la institución reacciona y al buscar las posibles causas las encuentra no dentro de la estructura eclesial sino fuera de ella. Los obispos muestran su defensa de la Iglesia que no admite la injerencia política. Su actitud es en su mayoría de hostilidad a los gobiernos liberales, incluso la Iglesia se siente perseguida. Lejos de entender el proceso político de cambio en cada momento, la mayor parte de los obispos se dedican más a recrear al pasado que a vislumbrar el futuro. La Iglesia no tuvo un papel dinamizador de la sociedad española, sino que fue a remolque de los acontecimientos, y le faltó adaptarse a una sociedad cada vez más urbana y moderna sin renunciar a sus principios evangélicos.

\section{FUENTES}

Archivio Segreto Vaticano

Congregatione de Concilio, Relationes Diocesium (fine sec. XVI-1908)

- Barcilonen 111B

- Derthusen 291

- Gerunden 363B

- Ilerden 399 B

- Tarraconen 785 B

- Urgelen 840

- Vicen 869 B 


\section{BibLIOgRAFíA}

Alonso, G. 2014. La Nación en capilla. Ciudadanía católica y cuestión religiosa en España (1793-1874). Granada: Comares Historia.

Andrés-Gallego, J. 2009. "Iglesia y Guerra en 1808: el estado de la cuestión». Ciudad de Dios: Revista agustiniana 222: 749-781.

Arnabat Mata, R. 2004. "La divisió de I’Església devant del constitucionalisme (el Trienni Liberal, 1820-1823)», en L. Plans (dir. y ed.), Església, societat i poder a les terres de parla catalana. Actes del IV congreso de la CCEPC (Vic, 20 i 21 de febrer de 2004): 263-278. Valls: Cosetània Edicions.

Arnabat Mata, R. 2013. La Guerra del Francès 200 anys després. Tarragona: URV.

Bada, J. 1986. L'església de Barcelona en la crisi de l'antic règim (18081833). Barcelona: Herder.

Barbastro, L. 1987. Revolución liberal y reacción (1808-1833): protagonismo ideológico del clero en la sociedad valenciana. Alicante: Gil Albert.

Barbastro Gil, L. 2013. El episcopado español y el alto clero en la Guerra de la Independencia (1808-1814). La huella del afrancesamiento. Alicante: Diputación de Alicante.

Barnosell Jordá, G. 2010. «La Guerra de la Independencia como guerra religiosa: el ejemplo de los sitios de Zaragoza y Gerona». Nuevo mundo, mundos nuevos 10. Disponible en: http://nuevomundo. revues.org/59671

Barrio Barrio, J. 1976. Fèlix Torres Amat (1772-1847): un obispo refor mador. Roma: Iglesia Nacional Española.

Barrio Gozalo, M. 2012. «El discurso politico-religioso del clero español en el contexto de la Guerra de la Independencia (1808-1813)». Anales valentinos: revista de Filosofía y Teología 75: 9-42.

Bonet i Balta, J. y Martí, C. 1990. L'integrisme a Catalunya. Les grans polèmiques, 1881-1888. Barcelona: Vicens Vives.

Borràs i Feliu, A. 2006. «La 'Librería Religiosa' de Barcelona i la renovació de la pietat a Espanya a mitjans del segle XIX (1848-1868)», en La recuperació d'un mite autòcton. El bisbe Caixal i el seu entorn històric (1803-1879): 38-39. Juneda: Fonoll.

Boutry, Ph. y Vincent, B. (coords.) 2002. Les chemin de Rome. Les visites Ad Limina à l'epoque moderne dans l'Europe meridiona et le monde Hispano-Américain (XVe. XIXe siècles. Roma: École Française de Roma.

Callahan, W. J. 1989. La Iglesia católica en España (1875-2010) Barcelona: Crítica.

Canal, J. 1998. El carlisme català dins I'Espanya de la Restauració. Vic: Eumo.

Cárcel Ortí, M. a M. y Cárcel Ortí, V. 1990. Historia, Derecho y Diplomática de la visita "ad limina». Valencia: Universidad de Valencia.

Cárcel Ortí, V. 1976. Correspondencia diplomática del nuncio Tiberi (1827-1834). Pamplona: Eunsa.

Closas Salinas, F. 2003. Església i poder a la Lleida del segle XIX. Control i mobilització social: Pedro Cirilo Úriz y Labayru (1850-1861). Lleida: Servei de Publicacions de la Universitat de Lleida.

Closas Salinas, F. 2004. «L'estada del bisbe Pedro Cirilo Úriz y Labayru a Lleida (1850-1861): poder polític i mobilització catòlica». Analecta Sacra Tarraconensia 77: 381-412.

Closas Salinas, F. 2015. «El obispo Pedro Cirilo Úriz y Labayru en la encrucijada del Concordato de 1851». Hispania Sacra 136: 673-715.

Corts i Blay, R. 1992. L'arquebisbe Fèlix Amat (1750-1824) i l'última II-Iustració espanyola. Barcelona: Herder, Facultat de Teologia de Catalunya.

Costa y Borrás, J. D. 1853. Exhortación Pastoral que el Excmo. e Ilmo. S. D. José Domingo Costa y Borrás, obispo de Barcelona, dirige a sus diocesanos. Barcelona: Imprenta de Pablo Riera.

Costa, M. 2011. "Mujeres y divorcio en Cataluña durante y posteriormente a la 'guerra del Francès' », en N. Sauch Cruz (ed.), La Guerra del francès als territoris de parla catalana: 263-273. CatarrojaBarcelona: Ed. Afers.

Cuenca Toribio, J. M. 2009. «El componente religioso en la Guerra de la Independencia», en E. de Diego (dir.), El comienzo de la Guerra de la Independencia: 48-68. Madrid: Actas.
De la Cueva Merino, J. 2015. «Conflictiva secularización: sobre sociología, religión e historia». Historia contemporanea 51: 365-395.

Feliu, G. 1972. La clerecía catalana durante el Trienio Liberal. Barcelona: IEC.

Ferrer, R. 2010 [1816]. Barcelona cautiva, ó sea diario exacto de lo ocurrido en la misma ciudad mientras la oprimieron los franceses. Edición de A. Moliner Prada. La Guerra del Francès a Catalunya segons el diari de Raimon Ferrer. Bellaterra: Servei de Publicacions de la UAB.

Figuerola, J. 1988. Església i societat a principis del segle XIX. La societat osonenca i el bisbe Strauch durant la crisi de l'antic règim. Barcelona: Eumo Editorial.

Figuerola, J. 1994a. El bisbe Morgades i la formació de l'Església catalana contemporània. Barcelona: Publicacions de I'Abadia de Montserrat.

Figuerola, J. 1994b. «Movimiento religioso, agitación social y movilización política». Historia Social 35: 43-63.

Figuerola, J., Martí, C. y Raguer, H. 2005. «Església i política. Algunes reflexions sobre la història i la historiografia», en L. Plans (dir. y ed.), Església, societat i poder a les terres de parla catalana. Actes del IV congreso de la CCEPC (Vic, 20 i 21 de febrer de 2004): 127128 y 134. Valls: Cosetània Edicions.

Fontana, J. 2008. La guerra del Francès 1808-1814. Barcelona: Pòrtic.

Fradera, J. M.a 1992. Cultura nacional en una societat dividida. Barcelona: Curial.

Fradera, J. M.a 1996. Jaume Balmes. Els fonaments racionals d' una política catòlica. Vic: Eumo.

Fradera, J. M. a 2002. "La religió, entre el vell món i el nou». Barcelona Quaderns d'Història 6: 105-119.

Fraser, R. 2006. La maldita guerra de España. Historia social de la Guerra de la Independencia (1808-1814). Barcelona: Crítica.

Fuentes, M. M. , Quijada, J. M. a y Sánchez, N. 2012. Memòria del Setge i ocupació de Tarragona. Tarragona: Arxiu Històric Arxidiocesà de Tarragona.

Gil Novales, A. 2010. Diccionario Biográfico de España (1808-1833). Madrid: Mapfre.

Girbau, V. 1992. "El bisbat de Vic a I' época del bisbe Veyan (17841815)». Pedralbes: Revista d' Història Moderna 12: 357-368.

Girbau, V. 1996. Església i societat a la Catalunya central: el bisbat de Vic a l'época del bisbe Veyan (1784-1815). Barcelona: Herder.

Ibáñez Gisbert, C. 1991. La diócesis de Tortosa en el pontificado de Monseñor Benito Vilamitjana i vila (1862-1879). Tortosa: UNED.

La Parra, E. 1998. «Los inicios del anticlericalismo español contemporáneo (1750-1833)», en E. la Parra y M. Suárez Cortina, El anticlericalismo español contemporáneo: 45-46. Madrid: Biblioteca Nueva.

La Parra, E. 2015. «La Iglesia ante la Guerra de la Independencia y en el reinado de Fernando VII (1808-1833)», en J. A. Escudero (dir.), La Iglesia en la historia de España: 855-867. Madrid: Marcial Pons.

La Parra, E. y Casado M.a A. 2013. La Inquisición en España. Agonía y abolición. Madrid: Catarata.

Laboa, J. M.a 1994. La Iglesia del siglo XIX. Entre la Restauración y la revolución. Madrid: Publicaciones de la Universidad Pontificia de Comillas.

Lara Martínez, M. 2011. Procesos de secularización en el siglo XVII y su culminación en el pensamiento ilustrado. Cuenca: Ediciones de la UCLM.

Marqués, J. M.a 2002. «La Iglesia de Gerona», en J. M.a Martí Bonet (coord.), Historia de las diócesis españolas. Vol. 2 Barcelona, Terrassa, Sant Feliu de Llobregat: 599. Madrid: BAC.

Martí, C. 1984. L'Església de Barcelona (1850-1857). Implantació social i dinamisme intern. Barcelona: Curial i Abadia de Montserrat.

Martí Bonet, J. M.a 2006. Historia de las diócesis españolas. Barcelona, Terrassa, Sant Feliu de Llobregat, Gerona. Madrid: BAC.

Martínez Ruiz, E. y Gil, M. 2010. La Iglesia española contra Napoleón. La guerra ideológica. Madrid: Actas.

Martínez San Martín, P. 1839. Pastoral dirigida a los eclesiásticos y a los fieles de su diócesis, anunciándoles pensamientos de paz y de caridad. Barcelona, 22 de marzo de 1839.

Moliner Prada, A. 1997. «El anticlericalismo popular durante el bienio 1834-1835». Hispania Sacra 49: 21-22 y 497-541. 
Moliner Prada, A. 1998. "Anticlericalismo y revolución liberal (18331874)», en E. la Parra y M. Suárez Cortina, El anticlericalismo español contemporáneo: 69-125. Madrid: Biblioteca Nueva.

Moliner Prada, A. 2000. Fèlix Sardà i Salvany y el integrismo en la restauración. Bellaterra: Servei Publicacions de la Universitat Autònoma de Barcelona.

Moliner Prada, A. 2002. "L'adaptació de l'església de Barcelona a la guerra i postguerra del francès», en Enfrontaments civils: postguerres $i$ reconstrucions. Segon congrés Recerques: vol. 1, 339-355. Lleida: Universitat Lleida, Pagès Editor.

Moliner Prada, A. 2005. «El papel de La Iglesia en la Guerra de la Independencia: de la movilización patriótica a la crisis religosa», en M. Reder Gadow y E. Mendoza García, La Guerra de la Independencia en Málaga y su provincia (1808-1814): 277-304. Málaga: Diputación de Málaga.

Moliner Prada, A. 2007. Catalunya contra Napoleó. La Guerra del Francès (1808-1814). Lleida: Pagès Editors.

Moliner Prada, A. 2011. Tarragona (mayo-junio 1811). Una ciudad sitia da durante la Guerra del francés. Madrid: CSIC, Ed. Doce calles.

Monod, J. C. 2013. Qué es la laicidad. Barcelona: Saber.

Pascual, P. 2000. Curas y frailes guerrilleros en la Guerra de la Independencia. Zaragoza: Institución Fernando el Católico.

Perea, E. 1993. El comportament religiós a Catalunya al segle XIX a la Diòcesi de Tarragona. El compliment pascual. Tarragona.

Pérez-Agote Poveda, A. 2007. «El proceso de secularización en la sociedad española». Revista CIDOB d'Afers Internacionals 77: 65-82.

Pons i Altet, J. M. a 2005. «Església i política a la Lleida de mitjan segle XIX: reconciliació, legitimació i conflictes», en L. Plans (dir. y ed.), Església, societat i poder a les terres de parla catalana. Actes del IV congreso de la CCEPC (Vic, 20 i 21 de febrer de 2004): 225-238. Valls: Cosetània Edicions.

Puigvert, J. M. 2000. Església, territori i sociabilitat (s. XVII-XIX). Vic: Eumo Editorial.

Ramisa Verdaguer, M. 1995. Els catalans i el domini napoleònic. Publicacions de l'Abadia de Montserrat.

Ramisa Verdaguer, M. 2008. Polítics i militars a la Guerra del Francès (1808-1814). Lleida: IEI.

Revuelta, M. 1979. «La Iglesia española ante la crisis del Antiguo Régimen (1808-1833)», en Historia de la Iglesia de España. V. La Iglesia en la España contemporánea (1808-1875): 67-68. Madrid: BAC.

Revuelta González, M. 1989. "La religión y las ideologías políticas», en Historia de España Ramón Menéndez Pidal, La época del romanticismo (1808-1874): XXXV, 161-163 y 201. Madrid: Espasa Calpe.

Revuelta González, M. 2005. La Iglesia española en el siglo XIX: desafíos y respuestas. Madrid: Universidad Pontificia de Comillas.

Revuelta González, M. 2009. «El sentido religioso de la Guerra de la Independencia», en J. M. Magaz Fernández (ed.), La Iglesia en los orígenes de la España contemporánea (1808): XXX. Madrid: Publicaciones de la Facultad de Teología San Dámaso.

Ritzler, P. R. y Sefrin P. F. 1968. Hierarchia Catholica Medii et Recentrois Aevi (1800-1846). Padua: Basilica de San Antonio.

Rodríguez López-Brea, C. M. 2002. Don Juis de Borbón el cardenal de los liberales (1777-1823). Albacete: Junta de comunidades de Castilla-La Mancha.

Roviró Alemany, M. 1998. "Marià Puigllat i Amigo (1804-1870) de la consolidació del tomisme a Vic a la vigatanització de Lleida». Ausa 140-141: 171-216.

Sánchez Carcelén, A. 2010. «Eclesiásticos catalanes y las Cortes de Cádiz». Anuario de Historia de la Iglesia 19: 119-140.

Sánchez Carcelén, A. 2012. Absolutisme i liberalisme: I'Església de Lleida durant el regne de Ferran VII. Barcelona: Rafael Dalmau Ed.

Sauch Cruz, N. (ed.) 2011. La Guerra del Francès als territoris de parla catalana. Catarroja-Barcelona: Ed. Afers.

Shubert, A. 1991. Historia social de España (1800-1900). Madrid: Nerea.

Subirá i Blasi, E. 1993. El seminari de Barcelona (1593-1917). Barcelona: Publicacions de l'Abadia de Montserrat.

Teruel, M. 1996. Obispos liberales. La utopía de un proyecto (18201823). Lleida: Milenio.

Toledano González, LL. F. 2001. Entre el sermó i el trabuc. El carlisme català contra la revolució setembrina (1868-1872). Lleida: Pagès editors.

Toledano González, LL. F. 2002. Carlins i catalanisme. La defensa dels furs catalans i de la religió a la darrera carlinada, 1868-1875. San Vicenç de Castellet: Farell.

Toledano González, LL. F. 2004. La muntanya insurgent. La tercera guerra carlina a Catalunya. Girona: Cercle d'estudis històrics i socials.

Vázquez Vilanova, J. A. 2002. "Los estudios en los seminarios españoles del siglo XIX. El ejemplo de la diócesis compostelana». Hispania Sacra 109: 227-242.

Yetano Laguna, A. M. a 2000. "Congregaciones religiosas femeninas: algunos datos sobre el movimiento fundacional en Cataluña durante el siglo XIX». Analecta Sacra Tarraconensia: Revista de ciències eclesiàstiques 73: 161-174. 